10.53116/pgaflr.2018.1.6

\title{
Abusus Iuris and the Protection of Public Interest by Administrative Authorities and (Administrative) Courts in Slovakia
}

\author{
Peter Potasch* \\ * Peter Potasch, Associate Professor, Dr. et Dr., PhD, Paneuropean University in Bratislava, Faculty of \\ Law, Institute of Public Law. (e-mail: peter.potasch@paneurouni.com)
}

\begin{abstract}
The presented paper deals with public interest in the decision-making practice of public authorities. The author also deals with the so-called abusus iuris (with focus on public law) which does not enjoy legal protection on the grounds that it is contrary to public interest. In this context, the author also points out that there is no uniform and universal definition of the concept/term of "public interest", but that public interest as such consists of partial public interests which may sometimes even be in conflict with one another thus comparing public interest and private interest in a certain case does not always have to suffice. He also points out certain procedural burdens relating to administrative proceedings - in particular the burden of sufficient reasoning and fact-finding especially in reference to the protection of public interest by administrative authorities. The paper primarily focuses on the decision-making practice of the courts of the Slovak Republic and of the Czech Republic - both at the level of protection of public interest in administrative proceedings and of its protection in court proceedings.
\end{abstract}

Keywords: good governance; administration; law

\section{Chapter 1}

The protection of public interest ${ }^{1}$ is undoubtedly an essential component of the functioning of the State, which as such also constitutes an element necessary for the existence of the State itself. However, the key questions we need and we strive to explore in this paper is what the protection of public interest is, where the boundaries of this institute are, under what circumstances is its application admissible and how its implementation is ensured so that it cannot be misused in such a way that referring to the protection of public interest would eventually become a "legitimate reason" for the issuance of an unlawful act by the public authorities.

First of all, it is necessary to consider whether "public interest" is something that is expressed in the Constitution of the Slovak Republic or in other generally binding legislation explicitly by (always) using the phrase "public interest". The answer is a very clear "no" and this makes the matter even more complicated and sensitive at the same time. The Constitution of the Slovak Republic and the laws of the Slovak Republic use a number of indications, which sometimes explicitly, sometimes descriptively indicate the protection of public interest. ${ }^{2}$ To illustrate, it is possible to point to some partial legal regulations, i.e. Art. 20 par. 2 of the Constitution of the Slovak Republic states "The law shall establish 
certain property, which is necessary for the purposes of safeguarding the needs of the society, the development of the national economy and the public interest, except the property defined in Art. 4 of this Constitution as the exclusive property of the State, the municipality or specific legal persons. A law may also lay down which property only individual citizens or legal persons residing in the Slovak Republic may own."3 (Explicit use of the term "public interest") Art. 20 par. 3 of the Constitution of the Slovak Republic states: "The ownership is binding. It shall not be misused causing harm to others or in contradiction with the general interests protected by the law. The exercise of right in property must not be detrimental to the health of other people, nature, cultural sites or the environment beyond the margin laid down by a law." (Use of the term "general interest" as a concept indicating the protection of public interest). Art. 20 par. 4 of the Constitution of the Slovak Republic further - "Expropriation or restrictions of right in property may be imposed only to the necessary extent and in public interest, based on the law and for a valuable consideration." 4

If we go to the level of inspecting the regulations defined by general Acts (rather than by the Constitution), it is evident that there are various Acts that protect public interest - (e.g. Act. No. 538/2005 Coll.) states - for example - that "The State Spa Commission will reject an application for a permit to use a resource if it is in the public interest not to use a natural healing resource or a natural mineral resource..." ${ }^{\text {. The }}$ provisions above (examples of sources of law) represent the legal basis of the protection of public interest in specific matters, while the protection of public interest can be (and most often is) realized in the decision-making processes of public authorities in particular cases. In this context, it is necessary to refer to administrative bodies, which decide about the rights, duties and rightful interests of natural persons and legal entities within the administrative procedure and who are obliged according to $\$ 3$ par. 1 of Act no. $71 / 1967$ Coll. (Code of Administrative Procedure) ${ }^{6}$ to protect the public interest in the decisionmaking process - "Administrative authorities shall act in accordance with laws and other legislation. They are required to protect the interests of the state and society, the rights and interests of natural persons and legal persons, and to consistently require the fulfilment of their duties." Where the protection of public interest is expressed by the phrase are required to protect the interests of the State and of society (the term corresponds to the time at which the aforementioned legal provision was formulated, the terminology equates to today's "public interest"). ${ }^{7}$ On the other hand, within the administrative judiciary we may encounter the protection of public interest expressed explicitly when $\$ 5$ par. 3 of Act no. 162/2015 Coll. - the Code on Administrative Judiciary - states that "In its decisionmaking the administrative court is committed to the protection of law and public interest." (SVK: "Pri rozhodovaní správny súd dbá na ochranu zákonnosti a verejného záujmu.")

The protection of public interest is specifically addressed in the Code on Administrative Judiciary e.g. with regard to the suspensory effect of the administrative action in relation to the decision to be subjected to judicial inquiry, which results from the provision of $\S 185$ (a) of the Administrative Proceedings Code, according to which "The administrative court may, following a motion by the claimant and the defendant's statement, grant a suspensive effect to a claim: (a) if the immediate execution or other legal consequences of the contested decision of the public authority or of the measure of the 
public authority would threaten to cause serious damage, whether substantial financial damage or economic damage, damage to the environment or any other serious irreparable consequences and the granting of a suspensive effect is not contrary to the public interest."

Finally, it must be concluded (within this general introduction) that there are more procedural provisions explicitly regulating the protection of public interest in public law decision-making procedure (i.e. by reference to the phrase "public interest" or other designation with similar content - e.g. Act no. 50/1976 Coll. Building Act states in its $\$ 81$ that "In the building approval [occupancy] proceeding, the building authority shall in particular examine whether the construction was carried out according to the documentation certified by the building authority in the construction procedure and whether the conditions of constructions specified by the zoning plan of the zone or the conditions specified in the territorial decision and in the building permit were observed. It shall further examine whether the actual construction or use of the structure will endanger the public interest, especially in terms of the protection of life and health of people and the environment, occupational safety and the safety of the technical equipment."). For the purposes of this paper we consider it sufficient to point out provisions of the law highlighted above, which we consider to be sufficient to illustrate the existing legal regime in which the protection of "public interest" is expressed in a direct way (directly).

\section{On the Protection of Public Interest (The Indirect Way/Method)}

However, the protection of public interest is not always provided for by a direct reference public interest in the source of law. With regard to the protection of public interest, it cannot be omitted that the legislation of the Slovak Republic recognizes a number of partial institutes - sometimes inspired by the legislation of foreign countries and incorporated into the legal order of the Slovak Republic, and some based on the decisionmaking activity of the European and/or international courts (with effects similar to those of the protection of public interest arising from the text of the Act explicitly [see above]). In the cases we will deal with in this section of the paper, there is no explicit definition of/ reference to the protection of public interest, ${ }^{8}$ i.e. the legislature does not use the phrase "public interest" or "general interest" (in the very source of the law) but through other legal expressions and legal regulations, it provides for the protection of public interest as a whole or a part thereof (e.g. in order to ensure quick and cost-effective judicial or administrative proceedings, to ensure the protection of public finances, etc.). Examples of such regulations include, for example, $\$ 5$ of Act no. 160/2015 Coll. Civil Proceedings Code for Adversarial Proceedings: "Obvious abuse of rights shall not involve legal protection. The court may, in so far as provided for in this Act, refuse and sanction procedural acts that are manifestly abusive, arbitrary or unlawful, or lead to unjustified delays in the proceedings." The provisions of $₫ 3$ par. 6 of Act no. 563/2009 Coll. on the Administration of Taxes and on Amendments to Certain Acts (hereinafter referred to as Tax Code), which is identical with the provisions of $\$ 2$ par. 6 of the previous Act no. 511/1992 Coll. on the administration of taxes and charges and on changes in the system of territorial financial authorities, with 
effect from 1 January 1993, regulated - without any substantive change - the principle of informality of the tax procedure according to which in the application of the various tax laws in tax administration, the actual/true content of the act or of other event crucial to finding, the levying or collection of taxes had to be taken into account.

As of 1 January 2014, the provision has been supplemented so that a legal relation or other fact crucial to finding, the levying or collection of taxes which have no economic justification and are resulting in targeted tax avoidance or obtaining such a tax advantage which the taxable entity would not otherwise be entitled to or resulting in a targeted reduction of tax liability shall be disregarded in tax administration. The purpose of the change in question was to allow the tax authorities to prevent tax administrators (tax authorities) from taking into account, for example, artificial transactions and structures created for unwanted tax optimization, even if such tax optimization is not the sole purpose of those transactions, and while avoiding an unjustified tax advantage under which it understands the unjustified application of claims resulting from tax legislation, such as a non-taxable portion of the tax base, the application of undue tax charges, the use of fictitious expenses, and the like. Thus, the question is related to the prohibition of abusus iuris in tax proceedings, which has already been recognized by the judicial practice even before, despite the absence of a specific statutory provision. For example, the Supreme Court of the Slovak Republic in its decision - file no. 2Sžf 44/2013 - stated that "the conduct of a taxpayer whose sole purpose is to obtain [tax] overcompensation and which conduct is devoid of any economic meaning, cannot be classified otherwise as an abuse of the objective law [abusus iuris] thus such conduct cannot be taken into account for tax purposes."

Understanding the prohibition of abuse of law/rights in court practice, based on the assessment of the economic meaning of the transaction by the taxpayer and the subsequent confrontation with the result in obtaining an unjustified tax advantage, the tax reduction for the entity is close to the formula used by the legislator in the amended provision of $₫ 3$ par. 6 of the Tax Code. Even in this case, these are facts which have no economic justification and which result in deliberate circumvention of a tax duty or acquisition of a tax advantage to which the taxpayer would otherwise not be entitled to or which results in a specific tax reduction. Under the aforementioned circumstances, therefore, it appears that the amendment does not impose any new rules of conduct, but only the settled judicial practice has been given the form of a statutory provision. From the use of the words purposeful circumvention, purposeful reduction, and advantage to which the entity would not be entitled to, it is beyond doubt, that the law here refers to acts that violate the law or obstruct it, and not what the law predicts directly - and combines the consequences in the form of benefits for the tax entity. Therefore, in order to apply this provision, an abusive application of the law/right must be exercised by the tax entity. In this context, it is necessary to define the concepts of the circumvention of the law and abuse of law/rights (abusus iuris) which are both present in civil and tax law, but with some differences, particularly in terms of legal consequences.

Bypassing (circumventing) the law is defined in the legal theory of civil law' in such a way that the legal act does not contradict the explicit wording of the statutory provision, however its consequences aim not to observe the objective of the law. Here the law refers 
not only to the Civil Code (Act No. 40/1964 Coll., the Civil Code), but also to other laws that have the force of an Act. Bypassing (circumventing) a law by legal action, in fraudem legis, is a behaviour that is based on the fact that someone does not act contrary to the law (contra legem), but in such a way as to deliberately achieve a result not foreseen by the law and/or a result that is undesirable. ${ }^{10}$ The Constitutional Court of the Slovak Republic stated that circumvention of the law consists of the exclusion of a legally binding rule of conduct with the deliberate use of means which are not forbidden by the law per se, as a result of which the established state of affairs appears to be incontestable in terms of law. Procedure in fraudem legis is a procedure whereby someone is formally acting under the law, but deliberately delivers a result that is prohibited, unforeseen or undesirable under legal rule. ${ }^{11}$ A legal act obstructing the law is invalid under $\$ 39$ of the Civil Code ( $\$ 39$ of the Civil Code reads: "A legal act whose content or purpose are at variance with an act, circumvent the act or are at variance with good manners shall be invalid." The fact that such conduct does not enjoy protection, can be derived from $\$ 3$ (1) of the Civil Code: "Exercise of rights and duties following from civil legal relationships must not groundlessly infringe rights and lawful interests of others and must not be at variance with good manners."

A broader understanding of circumvention in tax law vs. civil law is that it does not only deal with legal acts (the mere legality of the acts/of the conduct) but also with other matters that are critical for the discovery, collection or levying of taxes. For example, based on the case law of the Supreme Administrative Court of the Czech Republic, such a fact may be setting up and doing business through multiple companies in order to avoid the legal status of a value added tax payer. ${ }^{12}$ Another difference is in the legal consequences - while civil law relates circumvention of law with a legal consequence in the form of the invalidity of the legal act to which the circumvention relates (see above), tax law does not examine the question of the validity of the legal act at all, the circumstance circumventing the law, even if it was a legal act, is just simply not taken into account in tax proceedings/for taxation (tax) purpose (while not impacting in any way the very legal effect of the act itself). ${ }^{13}$ It is, therefore, a system of protection against abusus iuris (and thus also an instrument of protection of public interest) in the proceedings of the administrative body (the tax authority), who is under a duty to investigate whether a tax activity - showing otherwise - signs of a perfectly legal action, does not show signs of abusus iuris. If this is the case, the tax authority will evaluate this act as abusus iuris (e.g. an act damaging the public interest, such as reducing the tax liability of the person) with the relevant legal consequences not "accepting" that act for taxation (tax) purposes without directly affecting the legality (lawfulness/validity/binding effects) of the act itself.

In addition to the Tax Code (in the procedural regime), the Code on Administrative Judiciary (Act No. 162/2015 Coll.) also regulates the abuse of rights. Under $\$ 28$ of the Code on Administrative Judiciary, "The Administrative Court may exceptionally refuse actions brought by natural and legal persons, which are of a clearly vexatious nature or which pursue an abuse of law or its application to no avail. The administrative court may also sanction the parties' procedural acts that serve to abuse the laws, in particular to achieve delays in the proceedings." This provision of $₫ 28$ of the Code on Administrative Judiciary may be perceived as another ground for dismissing an action in connection with 
$\S 98$ (1) h) of the Code on Administrative Judiciary ("if so shall be established by this Act").

The basic parameters that need to be addressed ( $\$ 28$ of the Code on Administrative Judiciary) are as follows:

1. the application of such rejection is discretionary on the side of the court

2. exceptionality

3. dismissal of the action is carried out by a court decision

4. the grounds for refusal are

a) clearly vexatious nature of the action

b) abuse of law/rights (by the applicant)

c) unsuccessful application of the law (by the applicant)

The refusal of an action under $\$ 28$ is therefore a qualitatively different refusal than a refusal under the grounds set out in $\S 98$ of the Code on Administrative Judiciary. Rejection of an action for the reasons set out in the aforementioned provision of the Code on Administrative Judiciary is based on substantive facts relating to the action brought, while the concept of $\$ 28$ is completely different. $\$ 28$ covers the dismissal of an action, which is, in essence, an indirect penalization of the applicant for bringing an action, with a certain content or negative purpose (see above).

It should also be pointed out that there are several qualitative differences between the rejection of the application with reference to $₫ 98$ and with reference to $₫ 28$ of the Code on Administrative Judiciary - for example:

- the grounds for refusal under $\$ 98$ of the Code on Administrative Judiciary are in fact factually positive, objectively verifiable and without the discretion of the court, on the other hand - the grounds for refusal under $₫ 28$ of the Code on Administrative Judiciary are based exclusively on the court's own discretion (the vexatious nature of the action, or, as the case may be, on the Court's reasoning on the abusus iuris by the applicant), which should then be detailed, particularly regarding the abusus iuris as an instrument for the protection of public interest

- while $\$ 98$ of the Code on Administrative Judiciary regulates the so-called "mandatory" refusal of the action, the provision of $\$ 28$ regulates the option/ possibility of an administrative court to reject the action (not its duty/obligation).

The purpose of the provisions of $₫ 28$ of the Code on Administrative Judiciary is to prevent lawsuits from being brought into the system of administrative justice without real substantive justification, which would cause a slowdown in the overall performance of justice, both in the individual case before the court and in general too. The fact that the provision $\S 28$ of the Code on Administrative Judiciary is a tool for the protection against obvious abuse of the law/rights, also stems from the explanatory memorandum to the provision in question: This provision lays down the principle of the prohibition of obvious abuse of law/rights. The filing of an action by a natural person or a legal person abusing the law or following a harsh or expressly unsuccessful exercise of rights justifies its refusal under $\S 98$ par. (1) h. 
The existence of a prohibition of abuse of law/rights is derived primarily from the theory of law as a general legal principle, which is further developed by the case law of civil courts, administrative courts and of the Constitutional Court. The scholarly doctrine which one can refer to (see above), defines abusus iuris as a situation in which someone performs his or her subjective right thus causing unjustified harm to someone else or society - if so, such behaviour results in the illicit and is only apparently/formally permissible. ${ }^{14}$ This is the case of only apparently/formally permissible behaviour, because the law does not perceive a behaviour that could be both permissible and non-permissible at the same time. In the legal theory, the abuse of law/rights means the use of a legal rule inconsistent with its purpose. ${ }^{15}$ It is therefore an action apparently/formally permissible, that - however - eventually results in the circumvention of the law (circumventing its spirit and meaning) in order to deliberately achieve the result of a legal norm that is unforeseeable and undesirable. ${ }^{16}$

The Supreme Court of the Slovak Republic was also dealing with actions having vexatious, or "abusive" character in its judgement - file no. 5Sži/6/2012 in which the following opinion was expressed: "Concluding, the Supreme Court shall disclose that the Freedom of Information Act should not serve as a pretext for criticizing public authorities but as a tool of social control. The Supreme Court does not deny the applicant's right to information, but it is essential that this right be enforced effectively, i.e. only those requests that are genuinely required by those persons are to be addressed, i.e. requests for information within the scope of their decision-making activities. This is the only way to talk about effective social control of public administration. Otherwise, claimants could use this right as a pretext for formalistic and pointless disputes. One cannot overlook the fact that the control itself was carried out by the defendant in 2009 and the claimant as a civic association that 'watches politicians and points out where they steal, cheat and where they should behave more honestly, and proposes solutions to bring more decency and honesty to the political and public life' unnecessarily continued the administrative and legal proceedings for another three, or four years, although no more requested information could be provided by the directly concerned obligated person." i.e. in the explanatory statement (the reasoning) of the decision, the court indirectly identified the circumstances which could be subsumed under $\$ 28$ of the Code on Administrative Judiciary and at the same time under the heading of academic disputes (which - under standard circumstances - shall not be protected by the law and/or by courts). The Collection of Opinions and Decisions of the Supreme Court of the Slovak Republic - no. 5/2014 case no. 82 - also contains the following legal sentence (ratio decidendi): "The request for disclosure of information pursuant to Act no. 211/2000 Coll. on the free access to information (the Freedom of Information Act), as amended, is to serve only as a tool of social control and not as a means of misuse of law." (Judgment of the Supreme Court of the Slovak Republic of 28 February 2013, file no. 5Sži/6/2012) thus confirming the fact that in the conditions of the Slovak Republic, judicial protection should not be sought or exercised in such a way as to exercise a right that is harassing or abusive (by the party to the proceedings).

The Constitutional Court of the Slovak Republic in a resolution dismissing the complaint in the above-mentioned case (as manifestly ill-founded) accepted the procedure and the outcome of the Supreme Court of the Slovak Republic (see above), but at the same 
time pointed out the specificity of the case and the fact that such an approach cannot have a so-called template nature ("For the sake of completeness, in order to prevent misinterpretation, it must be added that the way in which the matter in question was legally understood can in principle be relied on in clear cases where it is clear that it is information from one office which is part of the loaned documentation that must be returned and does not become an information acquisition of the office to which the file was borrowed." [SVK: Pre úplnost' veci, v záujme zamedzenia dezinterpretácie, je nutné dodat', že spôsob, akým bola právne uchopená predmetná vec, môže byt' v zásade uplatnený pri jednoznačných prípadoch, kde je zrejmé, že ide o informáciu z jedného úradu, ktorá je súčastou zapožičanej spisovej dokumentácie, ktorá musí byt vrátená a nestáva sa takpovediac informačnou akvizíciou úradu, ktorému bola zapožičaná.]) - decision of the Constitutional Court of the Slovak Republic, file no. II. ÚS 482/2013, dated 3 October 2013. The Constitutional Court of the Slovak Republic thus "approved" the procedure (and the outcome) of the Supreme Court of the Slovak Republic in the matter, but at the same time, by means of some restrictive interpretation, it attempts to limit the application of the principle defined by the Supreme Court (in the above case) - by stating that this approach must not be considered to be a general rule and that all cases must be assessed on an individual basis.

It follows from the abovementioned short "legal trip" (to the Code on Administrative Judiciary) that, with effect as of 1 July 2016, the law of the Slovak Republic includes a positive, expressly stated right of the administrative court to refuse the administrative action (brought before it by an applicant) on the grounds that it has a vexatious character or presents an abuse of law/rights. However, with reference to the decision-making activity of the Constitutional Court of the SR, it must always be a sensible decision of the court (taking into account all the relevant circumstances of the particular case). Notwithstanding the above, it must be concluded that the abuse of law cannot be subject of evidence as a legal institute. The factual situation that is the result of the evidence obtained can be - once such factual situation is settled - legally assessed to be an abuse of law. Conclusion on the fulfilment of the facts of the abuse of law/rights is the result of a legal assessment of the settled state of affairs (facts). (Resolution of the Constitutional Court of the Slovak Republic of 7 June 2016, file no. III 355/2016-16)

\section{Public Interest and Its Protection in Specific Cases (Slovak Republic/Czech Republic)}

Public interest is (in most cases) a vague term, but this does not mean that the content of this term is to be formulated (or made up) by the administrative authorities themselves. ${ }^{17}$ The Supreme Administrative Court of the Czech Republic has unequivocally pronounced the legal opinion according to which "The principle of protection of the public interest does not mean that the public authorities should formulate public interest, more precisely public interests, themselves, which is, in principle, the task of legislative authority. It is the task of the administrative authorities, when applying the laws that define individual public interests, to specify - in particular cases - the generally expressed public interests." File no. 
6 As 65/2012, decision dated 10 May 2013, whereas the Constitutional Court of the Czech Republic several years before this decision of the Supreme Administrative court of the Czech Republic had established that "public interest in a particular case should be investigated during the administrative procedure on the basis of the measurement of a wide range of particular interests, after consideration of all contradictions and comments. The explanatory statement (the reasoning) for the administrative decision must then clearly indicate why the public interest outweighed a number of other specific interests. Public interest should be found in the decision-making process..." (28 June 2005, file no. Pl. ÚS 24/04).

Although the wording of the Czech Administrative Proceedings Code (in reference to public interest) is not identical to the verbal expression of the protection of public interest in the Slovak Republic ( $\$ 3$ [1] of the Administrative Proceedings Code), when it comes to the protection of public interest, the decision of the Czech Supreme Administrative Court can be useful. The said court in file no. 6 As 65/2012 stated that "The principle of protection of public interest by seeking and adopting solutions that are in accordance with the public interest is also one of the basic principles of administrative proceedings enshrined in $\$ 2$ (4) of the Administrative Proceedings Code. The formulation 'the accordance of the solution adopted with the public interest' then means the application of the provisions of laws expressing generally individual public interests in specific cases. In the administrative proceedings, several public interests are often against each other (or at least not completely in line) and it is not possible for the decision ultimately to be in line with all the public interests involved in the case. Furthermore, it is important to point out that administrative authorities should not formulate public interest themselves; this is, in principle, the task of the legislature; on the other hand, 'the task of the administrative authorities, when applying the laws that define individual public interests, to specify in particular cases the generally expressed public interests." (for more see: J. Vedral, Administrative Procedure: Commentary, 2nd Edition, Prague, Ivana Hexnerová - Bova Polyglon, 2012, p. 100).

It follows from this that public interest as a concept is not only vague without specific (general and universal) content, but rather - when deciding individual cases - it would be desirable to deal with various (and all relevant) specific public interests. Undoubtedly, there are many of such interests and they will not always be consistent (e.g. there may be a discrepancy between protection of the environment (as one specific public interest) and the public interest in the construction of motorways). It is unlikely that it would be possible to fully comply with all the particular interests in all cases. The decision-making of the Czech (administrative) courts - and in particular of the Supreme Administrative Court of the Czech Republic - (file no. 6 As 8/2010 dated 23 June 2011) confirms the concept of balancing when it explicitly requested that it was the duty of the administrative body "to weigh the collision of the public interest in the construction of this motorway and of the public interest in the protection of specially protected plant and animal species and to 'assess whether the proposed highway route is the optimal solution for the protection of specially protected plant and animal species'”. Similarly, the Municipal Court in Prague (file no. 11 Ca 41/2006 - decision dated 31 August 2006) concluded: "the distinct predominance of another public interest over the interest of nature conservation in 
accordance with $₫ 56$ of the Nature and Landscape Protection Act may be given only where the other public interest cannot be satisfied otherwise, without adversely affecting the natural development of specially protected species... It is the duty of the administrative authority to assess the consequences of the harmfulness of the construction intervention in relation to particular endangered species and to assess the particular facts to a greater extent, in connection with the existence of a distinctly overriding other public interest over the interest of nature conservation."

The assessment of public interest (sometimes occurring as a conflict of several subordinate/partial public interests) is therefore a matter of individualizing the decisionmaking process in a particular regime, in a particular legal context and taking into account the specific facts of the matter under consideration. Again, this is very well expressed in the decision of the Supreme Administrative Court of the Czech Republic (case no. 6As/65/2012), which states: "The Supreme Administrative Court, however, points out that even if the respondent had convincingly stated that the construction ad 1) was actually carried out in the public interest, it would have to be assumed that the public interest is a category with a specific content, in each case, which is dependent to the circumstances of the case". It is therefore necessary that "the public interest be explicitly formulated by the administrative authority in relation to the matter specifically addressed. It has to be deduced from the legal regulation and its components, from legal policy and assessment of various aspects according to the tasks of administration in the relevant fields (social, cultural, environmental protection etc.)" (Hendrych, D., cited above, p. 358).

In the case which was the subject of the decision of the administrative authorities and of the subsequent judicial review (see above), the administrative authorities have concluded that the construction for which the permit was sought was in public interest (i.e. it was in public interest to issue the permit). However, the administrative authorities failed to explain and assess how that element of public interest identified by them (interest in construction), related to and/or outweighed other public interests in the case. The Supreme Administrative Court of the Czech Republic stated (file no. 6/65/2012): "The Supreme Administrative Court therefore summarizes that it has come to the conclusion that the Municipal Court did not make a mistake when finding that the respondent has failed to provide adequate reasons for the public interest in the construction in the relevant locality where such construction affects the protection of specially protected species. Had there perhaps been an urgent public interest in the construction, it would not have been proven that it couldn't be satisfied with another solution that would achieve the desired intention while minimizing possible intervention in the protection of specially protected species of animals. In the case of the weighing of two public interests at conflict, as in the case of a collision of fundamental rights, the administrative authority must first identify and individualise the two public interests and then compare the gravity of both, while the intervention in either of the two protected public interests must not outweigh its positive effects. In addressing conflicts of public interest, it is necessary to maintain the maximum of the two conflicting interests, identifying the core and periphery of public interest, and at least the core of both public interests in play should be maintained."

The perception of public interest for the purpose of illustration in Slovakia could be carried out via the decision of the Regional Court in Košice in file no. 8S/26/2018 by 
which the administrative court ruled that the administrative action will not be granted a suspensive effect, (based also on the ground that the applicant had failed to establish that the suspensive effect - which he had requested - was not contrary to the public interest it follows from $\$ 185$ lit. [a] the Code on Administrative Judiciary). The application for the suspensory effect of the administrative action was based on the specifics of the application as follows: on the basis of a legally enforceable first instance decision in conjunction with the decision of the second instance administrative body: a registration at the Land Registry would allow to the relevant parties to the proceedings to acquire ownership of the properties included in the administrative decision/the Project, including those parties who did not pay compensation for the land or co-ownership interest in the account of the public body (the Fund), and did not show the will to become the landowners (etc.). On the question of the public interest, the application stated: 'The public interest in granting the suspensory effect of an administrative action in this case is not affected.' As stated above, pursuant to $\$ 185$ (a) of the Code on Administrative Judiciary, the administrative court may grant a suspensive effect (to the claim) if the immediate execution or other legal consequences of the contested administrative decision of the public authority or the measure of the public authority would threaten to cause serious damage, whether substantial financial damage or economic damage, damage to the environment or any other serious irreparable consequences and the granting of a suspensive effect is not contrary to the public interest.

With the introduction of a suspensory effect by law or admission under a decision of the administrative court under $\$ 185$ of the Code on Administrative Judiciary, the effects of the contested decision are suspended. The suspensory effect shall cease to be valid by the decision of the administrative court in the main proceedings ( $\$ 186[1], 2$ Code on Administrative Judiciary). If the administrative court does not accept the application, it will reject it ( $\$ 188$ Code on Administrative Judiciary). As is clear from the wording of $\$ 185$ (a) of the Code on Administrative Judiciary, the potential granting of suspensory effect to an action (i.e. to set aside the effects of the challenged administrative decision) is assessed by the court at the request of the applicant and after the defendant's statement has been provided. The granting of a suspensory effect is conditional, and the court must be satisfied that ordering a suspension would not be against public interest. The administrative court in the case under consideration has reached the following conclusion: (Regional Court in Košice, file no. 8S/26/2018) “... the wording of $\$ 185$ let. (a) of the Code on Administrative Judiciary provides for the applicant's duty in connection with his request for a suspensive effect to be granted by the court, not only to claim, but also to prove by means of evidence that the immediate execution or other legal consequences of the contested decision of the public authority threaten the consequences defined in $\$ 185$ (a) Code on Administrative Judiciary. [....] The applicant did not prove the facts in question before the administrative court and therefore the court did not even have to deal with the assessment of the potential contradiction between the granting of the suspensory effect and public interest when deciding on whether suspension shall be granted."

Apart from the fact that the administrative court in this case did not perceive the applicant (the Slovak Republic on whose behalf the Slovak Land Fund was acting) as an entity whose subjective rights may be affected by the decision, the application for the 
suspensive effect of the action was dismissed by the court on the grounds that in the court's view "the risk factors that the legislator refers to in relation to the possibility of a procedure were not proven by the applicant. The threat of serious harm, material, economic damage, financial damage, serious damage to the environment, or other serious irreparable damage, have not been substantiated and legally supported by the applicant in the case under review." The other element the court has to assess when deciding on the suspensory effect of a claim as per the Code on Administrative Judiciary, is the matter of potential contradiction with public interest (shall the suspension be granted). In this connection the court stated (in this very case) that "The Court further considers that, with regards to the public interest protected by the same dictum of $\$ 185$ let. (a) Code on Administrative Judiciary, any admission of the suspensory effect of an administrative action would not be in accordance with the case. The concept of "public interest" is an indeterminate legal concept which cannot be sufficiently defined, and its application depends on the assessment in each individual case. However, the settled case law regards the public interest as a generally beneficial interest, the bearer of which is the society and whose purpose is to ensure its optimal development. In the case in question, in the opinion of the administrative court, it is not disputed that the legal effects of long-term processes of arrangement of ownership relationships in gardening facilities are a priority public interest of the society."

It follows from the abovementioned explanatory statement of the court that the issue of public interest has been dealt with (by the court) in the case despite the fact the applicant did not specify any specific material arguments (details) relating to the public interest in his application (see above). We approve of such assessment of public interest by the court (despite of the applicant not providing any supporting arguments in his request for a suspension).

At the conclusion of this paper on the practical protection of public interest (within the framework of the activities of public bodies i.e. courts and administrative bodies), we would like to point to the decision of the Regional Court in Banská Bystrica (file no. $23 S / 118 / 2014$ ), in which the court deals with the potential abuse of law/right (by the claimant) - and the lawfulness of the action brought to court by the applicant in the context of the Freedom of Information Act. In accordance with the Act on Free Access to Information (No. 211/2000 Coll. - "the FOIA"), the applicant requested a very extensive set of information from the District Court of Zvolen (the applicant requested disclosure of all court proceedings which meet the following characteristics: a) the proceedings started at the District Court of Zvolen; b) the proceedings were registered in one of the " $\mathrm{C}$ ", "Cb", "Ro" or "Rob" registrars in accordance with the Decree of the Ministry of Justice of the Slovak Republic No. 543/2005 Coll., Annex No. 1, Chapter II, part B, point 1, or part (1) or part $(J) ; c)$ in the proceedings, the court has the obligation under Article $49(1)$ of the relevant Act to deliver documents (addressed to the claimant) only to Ulianko \& Holčík, s.r.o or Ulianko \& partners, s.r.o, with SNP 27, 96001 Zvolen, or if there are more claimants, the above duty of the court exists only to one of them; d) in the proceedings, the respondent, if he is a natural person, is not resident in the Zvolen district, or if he is a legal entity, he is not domiciled in the Zvolen district (district according to $\$ 2$ par. 33 of Act No. 371/2004 Coll.). From the procedures thus selected, the applicant requested information in the extent of: 
- file number assigned to the case at the District Court of Zvolen,

- the name of the judge managing the case,

- whether the matter was terminated at the District Court of Zvolen by transferral of the case to another court as per $\S 105$ par. 2 of the relevant Act.

The District Court of Zvolen (acting as the first instance administrative authority within the FOIA proceedings) rejected the request for information and did not provide the information requested by the applicant. The appellate authority (the Regional Court in Banská Bystrica - acting as an appellate administrative authority) upheld the administrative decision of the first instance administrative decision. The Regional Court in Banská Bystrica (acting as the relevant Administrative Court) subsequently examined the decision of the District Court of Zvolen as well as of the Regional Court in Banská Bystrica - on the basis of an administrative action brought by the applicant - and dismissed the action. The court also partially resorted to the abuse of law in its decision, claiming that "the new Code on Administrative Judiciary in $\$ 5$ par. 12 (Basic Principles of the Proceedings) establishes a novelty when the administrative court exceptionally may reject providing judicial protection to the rights of the natural person and the legal entity, and the application is subject to obvious abuse of rights. The provision in question refers to the protection of rights or to the legitimate interests of natural persons and legal persons and to avoid the execution of practices that are vexatious or are abusing the right to judicial protection to the detriment of other parties to legal relationships or public authorities."

The Regional Court in Banská Bystrica, expressed the legal opinion that the information requested by the applicant from the District Court of Zvolen (when looking at the quantity and the extent of the requested information) "is considered by the court to be an abuse of law/rights, as the Ulianko \& Holčík Law Firm in Zvolen, has been providing legal services for more than twelve years". The Court stated that: "From this point of view, the abuse of law/of the right to information may also be considered as a specific ground for refusing the claim brought to the court. In the present case, the applicant requested to provide a large amount of information from one entity - inter alia - whether 'the court has a duty under Article 49 of the relevant Act - to deliver the claimant's documents only to the Ulianko \& Holč́k Law Firm, or Ulianko \& Partners, with registered seat at Nám. SNP 27, Zvolen, or - if there are more claimants - if such duty exists to at least one of the claimants' - taking into consideration - that the law firm has been active for more than twelve years. Requiring such information does not provide for a reasonable arrangement of social relations, such conduct by the applicant may be an abuse of a subjective right and even have a vexatious nature. Providing such information is in violation of $\$ 5$ par. 12 of the Code on Administrative Judiciary and the Administrative Court in such cases where the action is vexatious or would contain an abuse of rights, does not provide the applicant with legal protection." 


\section{Conclusion}

The protection of public interest is implemented in the Slovak Republic by both substantive and procedural law provisions. While in some cases it is clearly identifiable that the protection of public interest is the primary purpose of the rule introduces by a source of law (in particular through the mandatorily expressed obligation of the administrative authority to take into account concepts such as "public interest", "general interest", "interest of society" etc.), in other cases, protection of public interest is carried out by other means (rather than expressly stating for the protection of public interest). It appears that both the Czech Republic and the Slovak Republic have accepted that public interest is a vague term in most cases without a clear definition of its content. Nevertheless, public interest must always have a legal basis and administrative authorities are not the ones tasked with "making up" the contents of public interest, rather, they are obliged to identify the specific interests involved in a particular case - either based on the very legal definition of public interest in a particular case (shall there be such definition expressly stated in the source of law) or specifying public interest(s) by looking into the very core of the laws they are applying in the decision-making. At the same time, it is without any doubts that "public interest" does not have a specific "universal" content, but public interests of different kinds should be - as a rule - perceived as complementary. On the other hand, sometimes inconsistency between particular public interests cannot be ruled out. In such cases, it is the duty of the administrative authorities not only to point to the factual and legal relevance of public interest versus private interest, but also to the links and relationships between the various partial public interests that may exist in the case. Balancing in categories of partial public interests should be clearly specified in the decision of the public authority. In the event of the existence of several partial public interests, the administrative authority should also deal within the reasoning of its decision, how it dealt with a specific public interest and why it was granted a specific/priority status over other interests involved. This does not relieve the administrative authority of the duty to act in such a way that the interference with all the particular interests concerned is as minimal as possible. 


\section{References}

1 As a preliminary point, we hereby note that the essence of this article is not the examination of the institute of public interest in the context of Act no. 357/2004 Coll. on the protection of public interest in the performance of functions of public officials, according to which "Public interest for the purposes of this Act is such an interest which brings property benefits or other benefits to all citizens or to many citizens."

2 In some sources of law, the lawmaker expressly uses the term "public interest" and defines what that public interest is. However, often this is not the case and the source of law frequently lacks a clear definition of the term public interest.

3 Constitution of the Slovak Republic, www.prezident.sk/upload-files/46422.pdf (accessed 5 February 2018)

4 Constitution of the Slovak Republic, www.prezident.sk/upload-files/46422.pdf (accessed 5 February 2018)

5 With $₫ 39$ para 1 defining what "public interest" would be for the purposes of the relevant Act.

6 For reasons of clarity, in the text the symbol $\S$ is used to refer to an article in a source of law, i.e. in an Act passed by the National Council of the Slovak Republic (the Parliament).

7 See also Soňa Kosiciarova, Správny poriadok. Komentár. [Administrative Procedures Act-Commentary] 24 (Šamorín, Heuréka, 2013). - "The second sentence of $₫ 3$ enshrines the tasks of administrative authorities in the exercise of their powers. They - by law - have the duty to protect the interests of the State and of the society. Currently a more modern term is used to describe this - namely public interest. It [public interest] refers to a legitimate public interest that enjoys legal protection. It is a general or a generally beneficial interest."

8 Lilla Garayová, Regulácia volného pohybu osôb v kontexte protiteroristických opatreni v EÚ. [The Regulation of the Free Movement of Persons in the Context of Counter-terrorism Measures] 1, Paneurópske právnické listy, 80-86 (2018).

9 For example, Jaromír Svoboda. et al. Občiansky zákonnik, I. diel, Komentár. [Civil Code, Commentary] 75 (Eurounion 1996).

10 Dušan Hendrych et al. Právnický slovník, [Legal dictionary] (3d. edition, Prague, C.H. Beck, 2009).

11 Finding of the Constitutional Court of the Slovak Republic - file no. III. ÚS 314/07 dated 16 December 2008.

12 Judgment of the Supreme Administrative Court of the Czech Republic 5 Afs 75/2011.

13 See in Karin Prievozníková, Implementácia zákazu zneužitia práva do daňového poriadku. [Implementation of the prohibition of abuse of rights in the Tax Code] 161 et seq. in Vladimír Babčák, Anna Románová, Ivana Vojníková (eds.) Daňové právo vs. daňové podvody a daňové úniky [Tax Law vs. tax frauds and tax evasion] (Košice, Univerzita Pavla Jozefa Šafárika, 2015).

14 Lilla Garayová, Spoločnost proti terorizmu? [Torture as a just means of preventing terrorism?], 360-364 (Plzeň, Aleš Čeněk, 2016).

15 Viktor Knapp, Teorie práva [Legal Theory] 184-185 (Prague, C. H. Beck, 1995).

16 Aleš Gerloch, Teorie práva [Legal Theory], 184 (Plzeň, Aleš Čeněk, 2013).

17 The content of the public interest is either expressly stated in the Act (e.g. $\$ 39$ of the Act on Mineral Waters - Act No. 538/2005 Coll.) or can be derived from the relevant act by looking into the aims and purpose of the regulation. 